\title{
Long-term effects of organic, conventional, and integrated crop systems on Carabids
}

\author{
Arnaud Legrand • Cédric Gaucherel • Jacques Baudry • \\ Jean-Marc Meynard
}

Accepted: 30 July 2010 /Published online: 8 March 2011

(C) INRA and Springer Science+Business Media B.V. 2011

\begin{abstract}
One of the main aims of sustainable agriculture is to reduce the risk of disease in cropping systems and thereby contribute to preserving public health and conserving the environment. In particular, if we are to reduce our recourse to agrochemicals, we need to acquire a deeper understanding of ecological processes, for instance biological pest control by predatory arthropods such as Carabids. We analyzed the population dynamics of a carabid (Pterostichus melanarius) in various cropping systems (conventional, integrated, and organic) to improve our limited knowledge of its potential impact on insect populations. To do this, we built a model composed of three coupled modules, each referring to different assumptions: a phenology module of the carabid species was based on a periodic Leslie-matrix model and a 1:1 sex ratio, the population was spatialized in Brittany (Western France) using a spatially implicit landscape module that simulated the capacity of grass margins to provide shelter for this carabid beetle, and an agronomic module was used to assess the effects of different crop management systems on the beetle population. Our results showed that the spread of P. melanarius larvae by farming practices was key to
\end{abstract}

A. Legrand $\cdot$ C. Gaucherel $\cdot$ J. Baudry

INRA UR980, CS 84215,

35042 Rennes Cedex, France

A. Legrand · J.-M. Meynard

Département Sciences pour l'Action et le Développement, INRA,

78850 Thiverval-Grignon, France

C. Gaucherel $(\square)$

UMR AMAP, EFPA, TA A.51 / PS 2,

34398 Montpellier Cedex 5, France

e-mail: gaucherel@cirad.fr species presence in crop fields. This was greatly dependent upon the farming calendar, the intensity of farming practices, and the presence of shelter zones. Maintaining and managing uncultivated habitats such as grass margins is thus as crucial for this beneficial predator as managing cultivated fields (asymptotic growth of the population was found to be $25 \%$ higher in integrated and organic management systems when $20 \%$ grass margins were present). At the field level, integrated management and direct drilling (with minimum disruption of the soil surface) are the best crop management systems for P. melanarius survival. Organic management is less effective (asymptotic growth of the population is only half that of integrated and direct-drilling management systems), for it requires multiple soil tilling to compensate for the absence of herbicides. Winter oilseed rape is the most detrimental crop (asymptotic growth of the population is half that seen with other crops), as it gives rise to summer molluscicides and soil tillage. This is the first study developing a numerical model of the long-term effects of landscape composition and cropping system on this beneficial predator species. This approach provides a powerful tool to test hypotheses and quantify their possible effects in agroecology.

Keywords Sustainable agriculture $\cdot$ Spatial modeling $\cdot$ Crop rotation $\cdot$ Population ecology $\cdot$ Organic farming $\cdot$ Direct drilling

\section{Introduction}

Reducing our recourse to pesticides is one of the main goals of sustainable agriculture and aims to preserve public health and conserve the environment, particularly its natural resources and biodiversity. If we are to control the risk of disease in 
cropping systems while at the same time reducing our recourse to agrochemicals, we need to acquire a deeper understanding of ecological processes such as biological pest control by predatory arthropods. Carabids play a role in preventing insect pest outbreaks through their predatory polyphagous nutritional habits (Kromp 1999). Pterostichus melanarius Illiger, 1788 (Coleoptera: Carabidae, also known as Platysma vulgare Linné, 1758) is one of the most abundant and widespread carabid species in Europe (Lys and Nentwig 1991; Thomas et al. 1998). This carabid is aggregated in fields (Fadl et al. 1996; Noordhuis et al. 2001; Thomas et al. 2001) and is a nocturnal generalist, ground-dwelling predator (Desender et al. 1985; Luff 1987). P. melanarius is particularly well known as an active species of potential economic importance as a biological control agent against aphids (Sunderland 1975; Dixon and McKinlay 1992; Kielty et al. 1999) and slugs in Northern European arable land (Bohan et al. 2000), as confirmed by gut dissections and ELISA tests (Chiverton 1984; Holland et al. 1996; Symondson et al. 1996). P. melanarius is a beneficial species that is sensitive to landscape structure (Jepson 1994) and to predator fauna that control pests (Kromp 1999). And yet, little is known of the effects of crop management systems and landscape structures on this species, and much would be gained if these were to be quantified and explored in depth.

The aim of our study was, therefore, to assess the effects of different cropping systems (conventional, integrated, and organic) on the demography and population movements of $P$. melanarius. Our main hypotheses were that grass margins and organic management should be more favorable to these population dynamics than other systems and landscapes. Because agricultural policies and market prices are constantly changing, it is quite a challenge to find landscapes and cropping systems that can be used to analyze their long-term effects on carabid populations. Models could, therefore, be used for this purpose, but to the best of our knowledge, no reports have been made in the literature of models used to determine the effects of landscape composition and cropping system on this beneficial species. Our intention was to quantify the impact of various farming techniques such as plowing, weeding, or insecticide spraying on various crops (winter oilseed rape, winter wheat, and spring pea). The model consisted of three successive coupled modules that will be described and discussed in the following order: first, a phenology module of $P$. melanarius was built with a periodic Leslie-matrix model to quantify population viability/extinction; then, the population was spatialized in Brittany (Western France) using a simple landscape-compartment module that simulated the capacity of grass margins to provide shelter for this carabid beetle; and finally, an agronomic module was used to assess the effects of different crop management systems on the population.

\section{Methods}

\subsection{Phenology module}

Leslie-Matrix projection models are well suited to represent the stage-classified life cycles of insects (Leslie 1945; Caswell 2001); here, the demography simulation took account of interannual variations in population density to assess sensitivity to agricultural interventions throughout the year at different stages (eggs, larvae, pupae, and adults). The time step chosen (10 days) was conditioned by the shortest stage transition time in P. melanarius and corresponds to the time necessary for eggs to become the first larval instar in Europe's oceanic climate (between 8 and 13 days according to Tréfás, personal communication). $P$. melanarius has three campodeiform larval stages, followed by a pupa, before emerging as an imago (Thiele 1977; Lövei and Sunderland 1996). To simplify the model, the first three larval stages were lumped together in a single larva stage containing eight classes, with only one class describing the total adult population. The population was represented at each time step $\mathbf{t}$ by a $13 \times 1$ vector $\mathbf{X}_{\mathbf{t}}$ of 13 classes: one class for the eggs, eight for the first larval instar, three for the pupae, and one for the adults, thus complying with the relative durations of each stage. Every class therefore had a 10-day duration. No stochasticity was included in the model, and population behavior was determined from the literature, when available, or set in accordance with current expert knowledge in the field. According to Tomlin (1975), the P. melanarius sex ratio is 1:1. A $13 \times 13$ female Leslie-matrix model was, therefore, developed which gave rise to the same demography as a $26 \times 26$ male-female Leslie-matrix model but runs faster. Matlab $^{\circledR}$ software was used for all the studies.

P. melanarius is a pure autumn breeder (Larsson 1939): it overwinters mainly as a larva, the first year in the center of fields (Lindroth 1968; Thiele 1977), then in the second year as a adult in field margins without any prereproductive summer aestivation (Paarman 1979) (Fig. 1). The Leslie-matrix diagonal allows each stage to be identical at each step $\mathbf{t}$ during overwintering (no development occurred during winter quiescence), with different survival rates for each stage. Because the first larval instar, pupae, and adults are all immobile chitinized stages in the soil when they overwinter, and because no life table was found in the literature, we chose to allocate them the same survival rate during the winter, i.e., 0.95 per time step. This species is a typical end-of-spring/beginning-of-summer breeder. Since eggs are laid on the soil surface in field margins and in field cores, the egg is the most vulnerable stage and sensitive to the winter climate (Lövei and Sunderland 1996). It, therefore, has a low survival rate which was set at 0.3 per time step. The result after each 


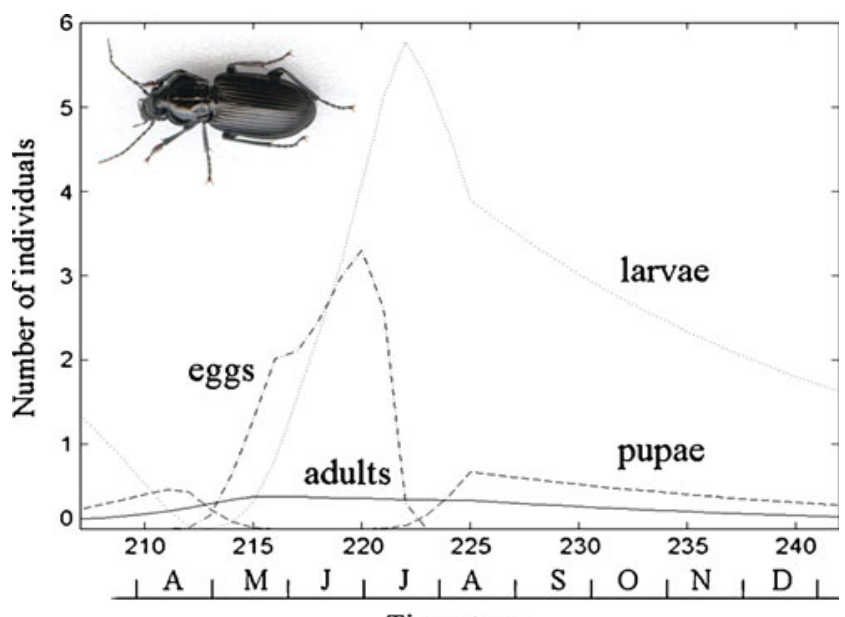

Time steps

Fig. 1 Simulated demography of the four P. melanarius (carabid, insert) stages. Eggs: dash-dotted, larvae: dotted, pupae: dashed, and adults: solid lines. Population dynamics are shown for months between April and December (letters) with a 10-day time step. Numbers of individuals show relative proportions between stages (i.e., densities). Please note that the various population stages are fairly synchronous

time step was a new $13 \times 1$ vector $\mathbf{X}_{\mathbf{t}+\mathbf{1}}=\mathbf{H} \cdot \mathbf{X}_{\mathbf{t}}$. The result after the overwintering period was a new vector $\mathbf{X}_{\mathbf{t}+\mathbf{1 8}}=$ $\mathbf{H}^{\mathbf{1 8}} \cdot \mathbf{X}_{\mathbf{t}} \cdot$ P. melanarius is active for 6 months as observed in Western Europe by Thiele (1977), whereas Firle et al. (1998) found adult $P$. melanarius to be active for at most 14 weeks in Sweden (ten time steps), probably due to lower temperatures and a shorter photoperiod during the winter (Fig. 1). Adults are very mobile and have a high survival rate of $98.5 \%$ after each time step, in spite of predation by various vertebrate species (Larochelle 1975, 1980).

The periodic matrix model was used to simulate intraannual variations in reproduction intensity during the activity season (Fig. 1): the $(1,13)$ cell $\mathbf{R}_{\mathbf{t}}$ of matrix $\mathbf{A}_{\mathbf{t}}$ received different egg production values per female depending on the time step (Hance 1990). P. melanarius oviposition takes place in the field from June to September (Wallin 1985, 1988; Holland et al. 1999). Total fecundity, with 98 eggs per female per year, was close to the 125 observed by Tomlin (1975). Reproductive intensity was assumed to be independent of habitat and crop management system, as observed by Lévesque et al. (1980) and Basedow (1994). No density dependency was added to the model, it being assumed that beetles do not interact one with another and do not deplete resources (Firle et al. 1998). Population size was given in relative values for a few hectares as no initial absolute values were available. The population multiplication rate $\lambda$, which is the dominant real eigenvalue in reducible matrix B (Caswell 2001), was estimated after applying (from the fifth year) the long-term agronomic module over 20 years, after stabilization was reached. The sensitivity of $\lambda$ to variations in stage was assessed by simultaneously varying all the parameters $x( \pm 10 \%)$ related to the classes of the stage in question. The elasticity, or normalized proportional sensitivity $E=x . d \lambda / \lambda . \mathrm{d} x$ of $\lambda$ to variations in stage, was then calculated to compare the relative impact of the different stages (using dedicated elasticities $\left.E_{\text {stage }}\right)$ of $P$. melanarius on its multiplication rate.

\subsection{Landscape module}

Adults migrate from field core to field margin before the overwintering period and a proportion migrates back into the field core early in the activity season (Stachow 1987; Hingst 1991). This spatial pendular movement was simulated by applying a spatially implicit landscape compartment module to the adult population such that population densities could be assessed separately in field cores and margins. This spatial module was multiplied by the phenology module to simulate the dispersal between landscape compartments. The model includes two types of field margin: hedgerow with or without a permanent grassy strip between the field and the hedgerow. This grassy strip, sometimes called a "beetle bank" is assumed to maintain Carabids in direct contact with crops (Wratten and Van Emden 1995). In our model, when a "beetle bank" was associated with the hedgerow, the Carabids migrated back and forth through the grassy strip before reaching the hedgerow. In this spatially implicit model, the Carabids were assumed to be uniformly distributed inside each compartment, thus in relative proportions to the land covers considered. The impact of effective dispersal abilities will be explored in a subsequent version of the model. In all, $75 \%$ of the Carabids were distributed in the field compartment, $20 \%$ in the grass compartment, and $5 \%$ in the hedgerow compartment $(95 \%$ in the field compartment and $5 \%$ in the hedgerow compartment when no grassy strip was added), which are common proportions in a French Brittany agricultural landscape. During the overwintering season, almost $100 \%$ of the adult Carabids were assumed to remain in the field margin compartment. The two migration periods were asymmetric because it takes more time for all the Carabids to emerge after overwintering and then colonize the other compartments than to directly migrate back to the overwintering habitat (Kromp 1999).

\subsection{Agronomic module}

The aim of this module was to simulate the long-term effects of cropping systems, i.e., cropping plans, rotations, and crop management, on the demography of $P$. melanarius. In order to simplify the first prototype of the model, only three classical arable crops of Western France were tested (Table 1): winter oilseed rape (Brassica napus L.), winter 
Table 1 Farming calendar for the simulated cropping system

\begin{tabular}{|c|c|c|c|c|}
\hline Date & Organic & Integrated & Direct drilling & Conventional \\
\hline \multicolumn{5}{|c|}{ Winter oilseed rape } \\
\hline Ju3 & Cultivator & $\begin{array}{l}\text { Plowing } \\
\text { Sowing }\end{array}$ & & Cultivator \\
\hline $\mathrm{Au} 2$ & $\begin{array}{l}\text { Plowing } \\
\text { Sowing }\end{array}$ & & Sowing & $\begin{array}{l}\text { Plowing } \\
\text { Sowing }\end{array}$ \\
\hline Au3 & & Molluscicide & $\begin{array}{l}\text { Insecticide } \\
\text { Molluscicide }\end{array}$ & $\begin{array}{l}\text { Insecticide } \\
\text { Molluscicide }\end{array}$ \\
\hline $\begin{array}{l}\text { F3 } \\
\text { Ap1 }\end{array}$ & & Insecticide & $\begin{array}{l}\text { Insecticide } \\
\text { Insecticide }\end{array}$ & $\begin{array}{l}\text { Insecticide } \\
\text { Insecticide }\end{array}$ \\
\hline \multicolumn{5}{|c|}{ Winter Wheat } \\
\hline $\begin{array}{l}\text { Ju3 } \\
\text { Au3 }\end{array}$ & $\begin{array}{l}\text { Cultivator } \\
\text { Plowing }\end{array}$ & Cultivator & & Cultivator \\
\hline $\begin{array}{l}\mathrm{S} 2 \\
\mathrm{O} 1\end{array}$ & Cultivator & Cultivator & & \\
\hline $\mathrm{O} 2$ & Cultivator & Cultivator & Sowing & $\begin{array}{l}\text { Plowing } \\
\text { Sowing }\end{array}$ \\
\hline $\mathrm{O} 3$ & & Sowing & & \\
\hline N1 & Sowing & & & \\
\hline N3 & $\begin{array}{c}\text { Mechanical } \\
\text { weeding }\end{array}$ & & & \\
\hline $\mathrm{F} 2$ & $\begin{array}{c}\text { Mechanical } \\
\text { weeding }\end{array}$ & & & \\
\hline Mr3 & $\begin{array}{c}\text { Mechanical } \\
\text { weeding }\end{array}$ & $\begin{array}{c}\text { Mechanical } \\
\text { weeding }\end{array}$ & & \\
\hline \multicolumn{5}{|c|}{ Phacelia/Spring Pea } \\
\hline Au1 & Cultivator & Plowing & & Cultivator \\
\hline $\mathrm{Au} 2$ & Sowing & Sowing & Sowing & Sowing \\
\hline D3 & Plowing & Cultivator & & Plowing \\
\hline $\mathrm{Ja} 2$ & Cultivator & & & \\
\hline $\mathrm{F} 1$ & Sowing & Sowing & Sowing & Sowing \\
\hline F3 & $\begin{array}{c}\text { Mechanical } \\
\text { weeding }\end{array}$ & Insecticide & Insecticide & Insecticide \\
\hline $\mathrm{Mr} 2$ & $\begin{array}{c}\text { Mechanical } \\
\text { weeding }\end{array}$ & & Insecticide & Insecticide \\
\hline
\end{tabular}

Model iterations use a 10-day time step. Only farming practices inducing direct mortality are mentioned

M3 the last third (i.e., days 20-30) of month M

wheat (Triticum aestivum L.), and spring pea (Pisum sativum L.). Again, this module was added as a matrix multiplying the two (phenology and landscape) other modules. A 10-day time step was sufficiently long to allow for completion of each intervention in the farming calendar. Pesticide spraying levels were assumed to be those recommended by agrochemical firms (dimethoate $400 \mathrm{~g} / \mathrm{ha}$; methiocarb $120 \mathrm{~g} / \mathrm{ha}$ ).

The depth of soil tillage operations was the main parameter used to model their impact on the different stages of $P$. melanarius. Sowing and direct drilling only affect the top few centimeters. Use of a cultivator and mechanical weeding affect about $10 \mathrm{~cm}$, whereas the moldboard plow tills about $20-30 \mathrm{~cm}$. The model showed that deep tillage did not seriously affect the adults, as previously observed by Baguette and Hance (1997), probably because they walk across the soil surface or bury themselves.

To simplify the model, mortality caused by insecticides, molluscicides, sowing, or soil tillage was considered to be independent of the time step and stable throughout the year. Mortality caused by insecticides and tillage was partially derived from estimations based on Bembidion lampros, another intensively studied field carabid (Table 2). Mortality caused by insecticide spraying was estimated from ecotoxicological studies on $P$. melanarius involving dimethoate, a broad-spectrum insecticide, and molluscicide spraying on $P$. melanarius with methiocarb, often considered the most effective ingredient of molluscicide pellets (Büchs et al. 1989). Because P. melanarius covers great distances in the course of a time step, recovery after insecticide spraying and migrations was considered to be independent of crop type and crop density (Chapman et al. 1999).

\subsection{Agronomic factors: sensitivity analysis}

Simulations were performed on the one hand with monocultures of winter wheat, spring pea, and oilseed rape to understand their respective effects on the population of $P$. melanarius and on the other with a common Western France rotation of winter oilseed rape/winter wheat/spring pea/winter wheat. P. melanarius is widespread in all these crops. A green fertilizer crop (phacelia) was assumed to be sown after the first wheat and buried before the sowing of spring pea. Various crop management systems were compared for this rotation, differing in soil tillage and insecticide and molluscicide treatments, and chemical or mechanical weeding (Table 1).

\section{Results and discussion}

Our objective was to use a matrix model to assess the effects of various cropping systems on the demography and population movements of $P$. melanarius. Phenology, landscape, and agronomical results are presented below and discussed.

\subsection{Phenology module}

The total number of insect individuals, including the four stages of the population, stabilized after 4 years in the simulation. The annual multiplication rate $\lambda$ was 1.149 , corresponding to the expected interannual exponential growth of density-independent matrix models. The demography of each stage of $P$. melanarius after stabilization 
Table 2 Mortality rates for Pterostichus melanarius (carabid) stages caused by different farming practices

\begin{tabular}{|c|c|c|c|c|c|c|}
\hline Stage & Depth of presence & Plowing & Cultivator/Mechanical weeding & Sowing & Molluscicide & Insecticide \\
\hline Eggs & $0-5 \mathrm{~cm}$ & $90 \%$ & $90 \%$ & $5 \%$ & $0 \%$ & $10 \%$ \\
\hline Larvae & $20-30 \mathrm{~cm}$ & $90 \%$ & $10 \%$ & $0 \%$ & $0 \%$ & $10 \%$ \\
\hline Pupae & $20-30 \mathrm{~cm}$ & $90 \%$ & $10 \%$ & $0 \%$ & $0 \%$ & $0 \%$ \\
\hline Adults & $0-15 \mathrm{~cm}$ & $20 \%$ & $10 \%$ & $0 \%$ & $25 \%$ & $80 \%$ \\
\hline
\end{tabular}

Estimations based on Purvis et al. 1988; Vickerman and Sunderland 1977; Hance and Grégoire-Wibo 1987; Purvis and Fadl 1996; Symondson et al. 1996; Büchs et al. 1989; Basedow 1994

(observed in year seven, time steps 207-242, i.e., from March to December, Fig. 1) showed a sharp increase during spring (in May and June). It then steadily decreased throughout the overwintering period and until reproduction started again.

Elasticity of multiplication rate $\lambda$ at all stages was mostly imposed by the life cycle and stages such as the first larval instar and adults that had the greatest number of classes (eight classes and a self-loop, respectively) resulted in high elasticity

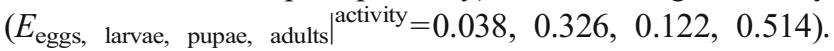
Adult survival rate during both the activity and overwintering seasons had the most impact on multiplication rate $\lambda$; with other stages having relatively little impact on $\lambda$ during the activity season and no impact during the overwintering season $\left(E_{\text {eggs, larvae, pupae, adults }}{ }^{\text {overwinter }}=0,0,0,1\right)$.

\subsection{Landscape module}

The simulations conducted with fields, hedges, and grass compartments (Fig. 2) showed that most adults were located in the field compartment from June to September. It was, therefore, in the summer that the adults were most exposed to agricultural practices. The model was validated qualitatively based on the data reported by Fadl and Purvis (1998), who trapped adult P. melanarius in the center of seven fields in Ireland, five of which were uncultivated and unsprayed grassleys: population emergence, maximum density, and decrease occurred at the same period in both the simulation and the experiment (not shown).

Population sizes in the three compartments were maintained in proportion to the relative surface areas of the three compartments during the activity season. Thomas et al. (1998) found that the activity-density of adult P. melanarius gradually increased between June and August and in midJuly almost all the Carabids caught had left the margin. Trapping data reported by Holland and Reynolds (2003) were compared with simulation results for the field compartment in the three-compartment model (Fig. 3). The two plots are presented such that maximum levels are superimposed. Emergence appeared to occur with the same intensity and activity peaked in July in both cases, but the experiment was not sufficiently long to provide data after July.

\subsection{Agronomy module}

We simulated the multiplication rate $\lambda$ of the P. melanarius population and compared winter oilseed rape, winter wheat, and spring pea monocultures under different crop management systems and with a grass margin present or absent (Table 3). Conventional management was the most detrimental system in our model for all monocultures and landscape compositions, drastically reducing $\lambda$ and systematically leading to population extinction. Organic management combined with monoculture also led to rapid extinction. Integrated management sustainably maintained $\lambda$ on oilseed rape, winter wheat, and spring pea. Direct drilling increased $\lambda$ with winter wheat and spring pea but systematically led to extinction with oilseed rape. Regardless of which management system was used, winter oilseed rape was the crop that had the most detrimental effects on $P$. melanarius populations (Table 3). Winter wheat and spring

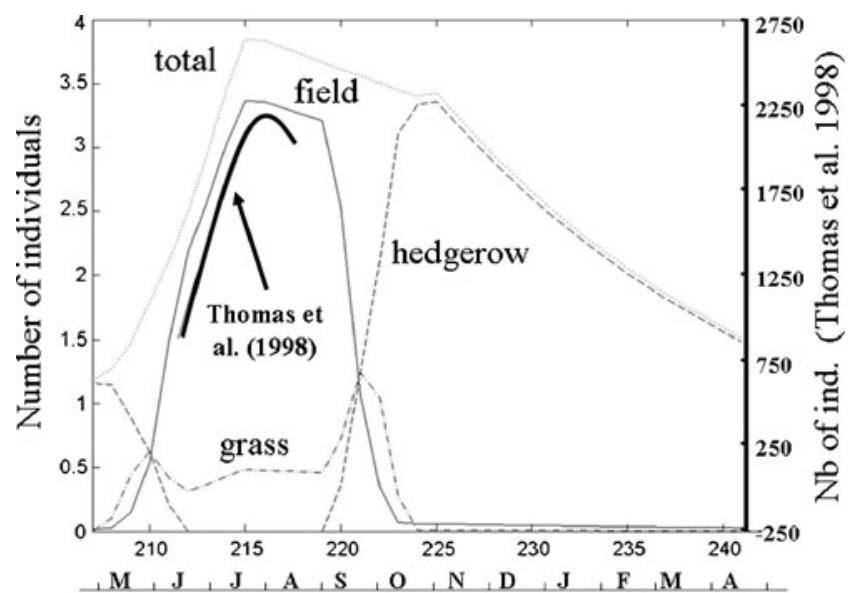

Time steps

Fig. 2 Simulated adult population of $P$. melanarius: total population (dotted line) in the field (solid line), the margin (dashed), and in $20 \%$ grass (dash-dotted). Simulated results, shown in relative proportions, are compared with total female adult Carabids estimated by Thomas et al. (1998) (bold solid line and right hand-side axis). Y-axis units have been scaled to superimpose the simulated and observed plots. They are in good agreement, with synchronous maxima during the year. Months are indicated by letters, with a 10-day time step. Note that migration between the landscape compartments occurs during the May-June and September-October periods 


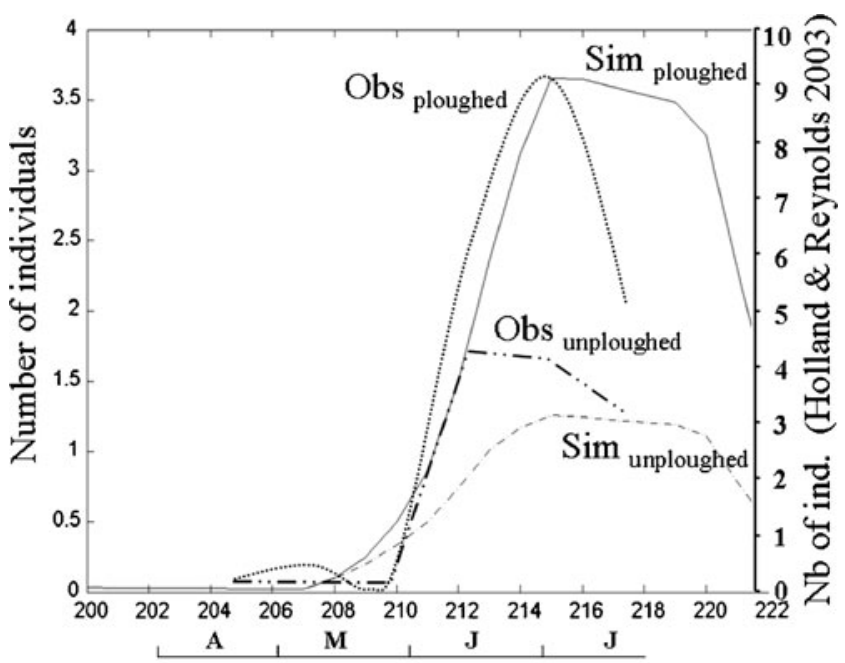

Time steps

Fig. 3 Simulated $\left(\operatorname{Sim}_{X}\right)$ and observed $\left(\mathrm{Obs}_{X}\right)$ adult P. melanarius populations on plowed (solid line and dashed lines, respectively) and unplowed (dash-dotted and double-dot-dashed lines, respectively) plots. Observations are adult catches per $5 \mathrm{~m}^{2}$ observed by Holland and Reynolds (2003). Y-axis units showing relative proportions of individual numbers have been scaled to superimpose simulated and observed plots. Note that they are in fairly good agreement, with synchronous increases during the year. Months are indicated by letters, with a 10-day time step

pea increased $\lambda$ with direct drilling and held it steady with integrated management, but conventional and organic management systems substantially reduced population density; $\lambda$ increased at most by 1.66 with integrated management on winter oilseed rape and by 1.46 and 1.58 with direct drilling management on winter wheat and spring pea, respectively (Table 3 ).

All model assessments at the field level (Figs. 2 and 3) were satisfactory, suggesting that the main hypotheses underpinning the model are correct. For each crop, field insecticide spraying, frequently in early spring (Table 1) when most adults are in the margins for overwintering, seemed to have relatively less impact than tillage on $P$. melanarius populations. We simulated the entire P. melanarius adult population and compared organic, integrated, direct drilling, and conventional management systems with the rotation of winter oilseed rape/winter wheat/(phacelia) spring pea/winter wheat, and with grass margin, for 20 years (Fig. 4). Direct drilling was the least detrimental treatment, decreasing initial population $\mathbf{X}_{\mathbf{1 4 4}}$ by only $\lambda=0.551$ after each rotation. It was also the only management regime that increased the adult population within a rotation by $\lambda=1.015$. Integrated management steadily decreased the population by $\lambda=0.464$ after each rotation throughout the simulation, but without extinction. Organic and conventional managements maintained respectively $\lambda=0.069$ and $\lambda=0.037$ of the initial population at each rotation, and led to population extinction during the 2 nd rotation. The "inter-rotational" population multiplication rate $(\lambda)$ for organic, integrated, direct drilling, and conventional crop management regimes (with $20 \%$ grass margin) corresponded to $0.191,0.649,0.684$, and 0.132 , respectively. Only the first and last led to population extinction after 20 years of simulation.

Our simulations showed winter oilseed rape management systems to be the most detrimental for P. melanarius (Table 3). Winter wheat and spring pea maintained the population under integrated and direct drilling management. Under organic and conventional management, intensive deep tillage during the reproduction period rapidly resulted in population extinction despite the presence of a grass margin (Fig. 4).

\subsection{Phenology module}

The model correctly simulated the expected population dynamics of $P$. melanarius. Elasticity tests highlighted how total reproduction intensity ( $\left.E_{\text {eggs }}\right)$ had little impact on $\lambda$, suggesting that $P$. melanarius has a "reproductive strategy" that is based more on its survival than on egg production (Thiele 1977). Our model is nevertheless fairly simple. Many other external factors may play a role in this complex insect-farmland system, and the model may be coupled with modules simulating predation on slugs and aphids, which can account for $84 \%$ and $64.4 \%$, respectively, of the gut contents of P. melanarius (Symondson et al. 1996;
Table 3 Interannual population multiplication rate $\lambda$ comparing landscape compositions and crop management systems for oilseed rape, winter wheat, and spring pea monocultures

Italicized values indicate exponential growth $(\lambda$ greater than one) and bold values indicate extinction after 20 years of simulation

\begin{tabular}{|c|c|c|c|c|c|}
\hline Landscape & Control & Organic & Integrated & Direct drilling & Conventional \\
\hline \multicolumn{6}{|c|}{ Oilseed rape monoculture } \\
\hline $0 \%$ grass & 1.149 & 0.556 & 0.631 & 0.551 & 0.237 \\
\hline $20 \%$ grass & 1.149 & 0.725 & 0.778 & 0.660 & 0.420 \\
\hline \multicolumn{6}{|c|}{ Winter wheat monoculture } \\
\hline $0 \%$ grass & 1.149 & 0.478 & 0.954 & 1.081 & 0.439 \\
\hline $20 \%$ grass & 1.149 & 0.623 & 0.988 & 1.091 & 0.604 \\
\hline \multicolumn{6}{|c|}{ Phacelia/Spring pea } \\
\hline $0 \%$ grass & 1.149 & 0.352 & 0.854 & 1.017 & 0.394 \\
\hline $20 \%$ grass & 1.149 & 0.544 & 0.929 & 1.043 & 0.572 \\
\hline
\end{tabular}




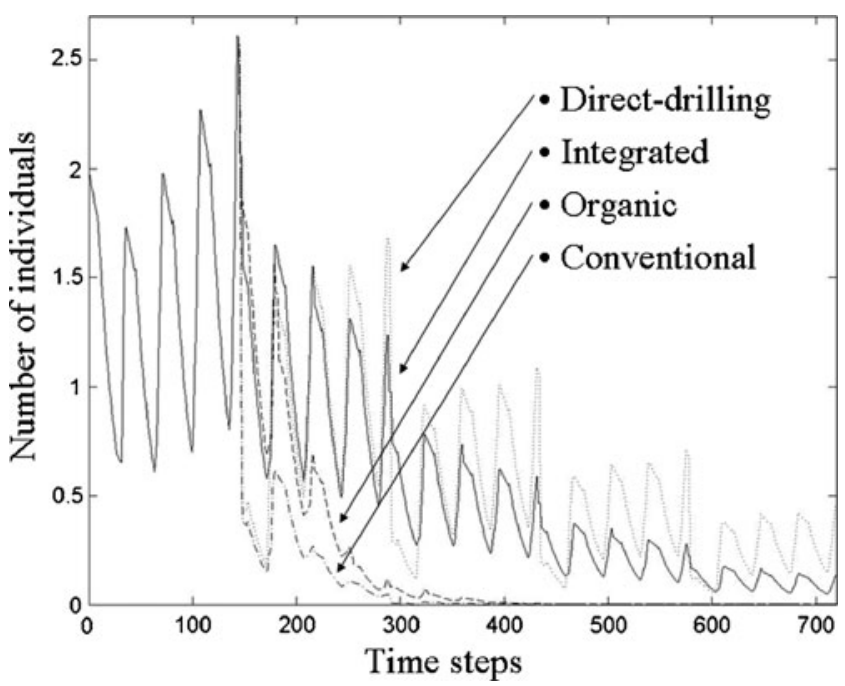

Fig. 4 Total P. melanarius adult population over 20 years comparing organic (dashed line), integrated (solid), direct drilling (dotted), and conventional (dash-dotted) treatments with the rotation oilseed rape/ wheat/pea/wheat but no grass margin. Crop management systems were all applied in the fifth year. All management regimes led more or less rapidly to population extinction in these simulations. The $y$-axis shows relative proportions of individual numbers, while the $x$-axis has a 10-day time step

Hance 1990). Diversity of soil structure, hydromorphology (Kromp 1999), and climate (temperature, air and soil humidity, etc.) may affect the ability of carabid beetles to bury themselves, reproduce, or lay eggs in the soil (Holliday and Hagley 1978; Thomas et al. 1998, 2001; Lövei and Sunderland 1996). Also, our model could easily be applied to other species if sufficient data about phenology, spatial behavior, and farming-induced mortality are available.

\subsection{Landscape module}

How do landscape structures affect overall dynamics? The general trend seen here was for cropping systems to cause a more or less drastic collapse of the $P$. melanarius population, with some simulations even leading to extinction. This reduction was sometimes quantitatively limited by grass margins that provided shelter zones, but the qualitative result was unchanged. However, P. melanarius is one of the most common species in European arable lands, and its capacity to adapt in anthropized habitats may allow it to withstand the pressure exerted by intensive agriculture. Although the spatially implicit landscape compartment module was able to represent global migrations throughout the year, it may be necessary to introduce a spatially explicit module (Topping et al. 2003; Gaucherel et al. 2006) to capture the fact that $P$. melanarius covers great distances every day and is, therefore, very likely to pass through several compartments in a short period. This would also help simulate migrations induced by chemical spreading or tillage, which is not yet taken into account in the model. A spatially explicit version of the model that includes effects due to the spatial diversity of crops, which is particularly marked in organic management, could be more favorable to the organic system (in terms of population dynamics) than is this current version.

Our model's spatial module did not consider landscape fragmentation or hedge network connectivity (Burel 1989; Burel and Baudry 2003). The stochasticity or variability of P. melanarius movements could also be added to the model and thereby include the diversity of spatial distributions and P. melanarius movements in relation to land use (Frampton et al. 1995; Wallin and Ekbom 1988; Mauremooto et al. 1995) or satiation state (Wallin and Ekbom 1994; Frampton et al. 1995; Mauremooto et al. 1995; Fournier and Loreau 2001; Thomas et al. 2001).

\subsection{Agronomy module}

Our model simulated $P$. melanarius dynamics in various monocultures and different crop management systems. Conventional management and winter oilseed rape were found to have the most detrimental effects on P. melanarius populations, drastically reducing $\lambda$ and systematically leading to population extinction (Table 3). Integrated management sustainably maintained $\lambda$ on oilseed rape, winter wheat, and spring pea but led to population extinction when no grass margin was present with winter oilseed rape. This might be due to top soil drilling when many larvae and pupae are in the field in summer. Direct drilling increased $\lambda$ with winter wheat and spring pea but systematically led to extinction with oilseed rape. But direct drilling led to higher P. melanarius densities than conventional management as observed by Symondson et al. (1996). In all cases, crop management systems other than conventional increased $\lambda$, except organic management with winter wheat and spring pea.

Assessments of the model at the field level (Figs. 2 and 3) were fairly satisfactory, in particular the method used to simulate the detrimental effects of plowing on P. melanarius populations. This method was based on logical assumptions that were themselves based on published rather than experimental data, and was qualitatively validated by the agreement between its results and the observations made by Holland and Reynolds (2003). Field insecticide spraying appeared to have relatively less impact than tillage on $P$. melanarius populations and this, regardless of the crop. This explains why organic management that received no insecticides but more intensive tillage than conventional management produced very similar results. Also, the cropping system effect presented here must be considered with caution and cannot be systematically generalized to other beneficial species or pests. 
Our 20-year simulation of the total P. melanarius adult population compared organic, integrated, direct drilling, and conventional management systems using various crops without a grass margin (Fig. 4). The idea, on the one hand, was to compare management regimes without (direct drilling) and with plowing and, on the other hand, to compare conventional with other (organic and integrated) management systems. Direct drilling was the least detrimental treatment. Adding grass margins spared by farming practices increased the total adult population in all the crop management systems used, as suggested by Thomas et al. (1994), but no positive $\lambda$ was observed after any rotation. Our simulations showed that the population in organic and conventional management systems was too small to benefit from grass margins. And only organic and conventional crop management systems (with $20 \%$ grass margins) led to population extinction.

Winter oilseed rape management systems are characterized in July and August by intensive tillage (organic, conventional, and integrated) and molluscicide or insecticide spreading (conventional, integrated, and direct drilling; Table 1). As larval emergence peaks during these summer months (Fig. 1), this explains why the model indicated that this crop was the most detrimental for P. melanarius (Table 3). Winter wheat and spring pea maintained the population under integrated and direct drilling management systems because very few aggressive interventions were made during the larval emergence period (reproduction period). The intensive deep tillage employed in organic and conventional management systems during the reproduction period was, therefore, the main factor impacting on the dynamics of $P$. melanarius (Fig. 4). It is, therefore, crucial to assess the interactions between the larval emergence period, the presence of a weakly chitinized first larval instar in the field compartment, and the farming calendar for the crop management system employed when assessing the capacity of a cropping system and a landscape structure to foster the development of $P$. melanarius, as previously suggested by Hance (1990) or Lövei and Sunderland (1996).

\section{Conclusion}

This study aimed to model the dynamics of a P. melanarius population under various cropping systems. To the best of our knowledge, very few current models are able to couple ecological and agronomic processes to simulate the effects of different cropping systems and landscape compositions on a species (Gouyon et al. 2001; Colbach et al. 2001; Bilde and Topping 2004). Our model explained the possible phenology of poorly known stages of $P$. melanarius with and without farming activity. If model assumptions are valid, the results presented here illustrate that if farms and beneficial carabid beetles are to coexist, cropping practices must spare the first larval instar. This is greatly dependent upon the farming calendar, the intensity of cropping practices, and the presence of shelter zones. Maintaining and managing uncultivated habitats such as margins or grassy strips is thus as crucial for carabid beetles as managing cultivated fields.

Since the present version of the model is not spatially explicit and does not take account of landscape diversity, no reliable comparison can as yet be made of cropping systems at the landscape level. For this reason, only sensitivity analyses (to different crop management systems or to crop species) were performed. At the field level, integrated management and direct drilling are probably the best crop management systems for $P$. melanarius survival. Organic management appeared to be less effective at the field level because it needs many soil tillages to compensate for the absence of chemical weeding. Winter oilseed rape was the most detrimental crop, due to summer molluscicide treatment and soil tillage. But, the longterm effects of crop management and rotations are still poorly understood, and other changes in rotation or landscape composition could enhance their capacity to control pests. We could then recommend new experiments to test these hypotheses and investigate the response of other carabid species on the basis of such simulations. Once improved, the model should be able to compare cropping systems and landscape compositions and thereby help establish methods to maintain carabid populations in the long term.

Acknowledgements The authors are grateful to R. Bommarco, $\mathrm{K}$. Booij, P. Bouchard, P. Brandmayr, H.l Caswell, N. Elliott, W. French, A. Garnier, T. Hance, J. Helenius, J. Holland, N. Holliday, J. Ingerson-Mahar, W. Kipling, M. Lesnoff, C. Levesque, J. Liebherr, M. Luff, D. Mossakowski, J. Niemelä, J.-B. Pichancourt, G. Purvis, F. Sarrasin, W. Symondson, R. Thacker, G. Thomas, H. Tréfás, and M. Varvara for generously providing literature or assistance. This work was supported by INRA and the DIVA program of the French Ministère de l'Ecologie et du Développement Durable. This work was funded by the Agence Nationale de la Recherche (project "BiodivAgriM", ANR-biodiversité 2007).

\section{References}

Baguette M, Hance T (1997) Carabid beetles and agricultural practices: influence of soil plowing. Biol Agric Hortic 15:185190

Basedow T (1994) Phenology and egg production in Agonum dorsale and Pterostichus melanarius (Col., Carabidae) in winter wheat fields of different growing intensity in Northern Germany. In: Desender $\mathrm{K}$ et al (eds) Carabid beetles: ecology and evolution. Kluwer, Dordrecht, pp 101-107

Bilde T, Topping C (2004) Life history traits interact with landscape composition to influence population dynamics of a terrestrial arthropod: A simulation study. Ecoscience 11(1):64-73

Bohan DA, Bohan AC, Glen DM, Symondson WOC, Wiltshire CW, Hughes L (2000) Spatial dynamics of predation by carabid beetles on slugs. J Anim Ecol 69:367-379 
Büchs W, Heimbach U, Czarnecki E (1989) Effects of snail baits on non-target carabids. In: Henderson IF (ed) Slugs and snails in World agriculture. Monograph No. 41. Thornton Heath: British Crop Protection Council 245-252

Burel F (1989) Landscape structure effects on carabid beetles spatial patterns in Western France. Landscape Ecol 2:215-226

Burel F, Baudry J (2003) Landscape ecology-Concepts, Methods and Applications. Science, Enfield, p 362

Caswell H (2001) Matrix population models: construction, analysis and interpretation, 2nd edn. Sinauer, Sunderland

Chapman PA, Armstrong G, McKinlay RG (1999) Daily movements of Pterostichus melanarius between areas of contrasting vegetation density within crops. Entomol Exp Appl 91(3):477-480

Chiverton PA (1984) Pitfall-trap catches of the carabid beetle Pterostichus melanarius, in relation to gut contents and prey densities, in insecticide treated and untreated spring barley. Entomol Exp Appl 36:23-30

Colbach N, Clermont-Dauphin C, Meynard JM (2001) GENESYS: A model of the influence of cropping system on gene escape from herbicide tolerant rapeseed crops to rape volunteers.I. Temporal evolution of rapeseed volunteers in a field. Agric Ecosyst Environ 83:235-253

Desender K, van den Broeck D, Maelfait JP (1985) Population biology and reproduction in Pterostichus melanarius Ill. (Coleoptera, Carabidae) from a heavily grazed pasture ecosystem. Meded-Fac-Landbouwwet-Rijksuniv, Vol. 50(2b). Gent: Het Faculteit, pp. 567-575. (incomplete paging)

Dixon PL, McKinlay RG (1992) Pitfall trap catches of aphid predation by Pterostichus melanarius and Pterostichus madidus in insecticide treated and untreated potatoes. Entomol Exp Appl 64:63-72

Fadl A, Purvis G (1998) Field observations on the lifecycles and seasonal activity patterns of temperate carabid beetles (Coleoptera: Carabidae) inhabiting arable land. Pedobiologia 42:171-183

Fadl A, Purvis G, Towey K (1996) The effect of time and soil cultivation on the incidence of Pterostichus melanarius (Ill.) (Coleoptera: Carabidae) in arable land in Ireland. Ann Zoologici Fennici 33:207-214

Firle S, Bommarco R, Ekbom B, Natiello M (1998) The influence of movement and resting behaviour on the range of three carabid beetles. Ecology 79(6):2113-2122

Fournier E, Loreau M (2001) Activity and satiation state in Pterostichus melanarius: an experiment in different agricultural habitats. Ecol Entomol 26:235-244

Frampton GK, Cilgi T, Fry GLA, Wratten SD (1995) Effects of grassy banks on the dispersal of some carabid beetles (Carabidae: Coleoptera) on farmland. Biol Conserv 71:347-355

Gaucherel C, Giboire N, Viaud V, Houet T, Baudry J, Burel F (2006) A domain specific language for patchy landscape modelling: the Brittany agricultural mosaic as a case study. Ecol Modell 194:233-243

Gouyon PH, Meynard JM, Klein E, Angevin F (2001) Modéliser l'impact des OGM: pourquoi et comment? Comptes Rendus de 1'Académie d'agriculture de France

Hance Th, Grégoire-Wibo C (1987) Effect of agricultural practices on carabid populations. Acta Phytopathologica Entomologica Hungarica, 22(1-4): 147-160.

Hance T (1990) Relationships between crop types, carabid phenology and aphid predation in agroecosystems. In: Stork NE (ed) The role of ground beetles in ecological and environmental studies. Intercept, Andover, pp 55-64

Hingst R (1991) Die Bedeutung der Wallhecken für die Knickversetzung und der Verbund von Ökosystemen. Faunist Ökol Mittn (Kiel) 10:71-99

Holland JM, Reynolds CJM (2003) The impact of soil cultivation on arthropods (Coleoptera and Araneae) emergence on arable land. Pedobiologia 47:181-191
Holland JM, Thomas SR, Hewitt A (1996) Some effects of polyphagous predators on an outbreak of cereal aphid (Sitobion Avenae F.) and orange wheat blossom midge (Sitodoplosis mosellana Géhin). Agric Ecosyst Environ 59:181-190

Holland JM, Perry JN, Winder L (1999) The within-field spatial and temporal distribution of arthropods in winter wheat. Bull Entomol Res 89:499-513

Holliday NJ, Hagley EAC (1978) Occurrence and activity of ground beetles (Coleoptera: Carabidae) in a pest management apple orchard. Can Ent 110:113-119

Jepson PC (1994) Field margins as habitats, refuges and barriers of variable permeability. BCPC Monogr 58:67-76

Kielty JP, Allen Williams LJ, Underwood N, Eastwood EA (1999) Behavioral responses of three species of ground beetle (Coleoptera: Carabidae) to olfactory cues associated with prey and habitat. J Insect Behav 9(2):237-250

Kromp B (1999) Carabid beetles in sustainable agriculture: A review on pest control efficacy, cultivation impacts and enhancement. Agric Ecosyst Environ 74:187-228

Larochelle A (1975) A list of mammals as predators of Carabidae. Carabidologia 3:95-98

Larochelle A (1980) A list of birds of Europe and Asia as predators of carabid beetles including Cicindelini (Coleoptera: Carabidae). Carabidologia 3:99-103

Larsson SG (1939) Entwicklungstypen und Entwicklungszeiten der Dänischen Carabiden. Entomologiske Meddelelser 20:277-560

Leslie PH (1945) On the use of matrices in certain population mathematics. Biometrika 33:193-212

Lévesque C, Pilon J-G, Dubé J (1980) Observations sur les oocytes de quelques Coléoptères Carabidae du Québec. Ann Soc Entomologique Qué 25(1):1-9

Lindroth GH (1968) The ground beetles of Canada and Alaska. Part 5. Opuscula Entomologica Supplementum 33.296 pp

Lövei GL, Sunderland KD (1996) Ecology and behavior of Ground Beetles (Coleoptera, Carabidae). Annu Rev Entomol 41:231-256

Luff ML (1987) Biology of polyphagous ground beetles in agriculture. Biology and population dynamics of invertebrate crop pests. Agric Zool Rev 2:237-278

Lys J, Nentwig W (1991) Surface activity of carabids inhabitating cereals fields. Pedobiologia 35:129-38

Mauremooto JR, Wratten SD, Worner SP, Fry GLA (1995) Permeability of hedgerows to predatory carabid beetles. Agric Ecosyst Environ 52:141-148

Noordhuis R, Thomas SR, Goulson D (2001) Overwintering populations of beetle larvae (Coleoptera) in cereal fields and their contribution to adult populations in the spring. Pedobiologia 45:84-95

Paarman W (1979) Ideas about evolution of the various annual reproduction rhythms in carabid beetles of the different climatic zones. Miscellaneous Papers 18. Landbouwhogeschool, Wageningen, pp 119-132

Purvis G, Carter N, Powell W (1988) Observations on the effects of an autumn application of a pyrethroid insecticide on non-target predatory species in winter cereals. Pages $153-166$ in R. Cavarello \& K.D. Sunderland (eds.). Integrated Crop Protection in Cereals. A. A. Balkena, Rotterdam.

Purvis G, Fadl A (1996) Emergence of Carabidae (Coleoptera) from pupation: a technique for studying the "productivity" of carabid habitats. Ann. Zool., Fennici 33: 215-223.

Stachow U (1987) Aktivitäten von Laufkäfern (Carabidae; Col.) in einem intensive wirtschaftenden Ackerbaubetrieb unter Berücksichtigung des Einflusses von Wallhecken, Ph. D. Thesis, University of Kiel

Sunderland KD (1975) The diet of some predatory arthropods in cereal crops. J Appl Ecol 12:507-515 
Symondson WOC, Glen DM, Wiltshire CW, Langdon CJ, Liddell JE (1996) Effects of cultivation technique and methods of straw disposal on predation by Pterostichus melanarius (Coleoptera: Carabidae) upon slugs (Gastropoda: Pulmonata) in arable field. J Appl Ecol 33:741-753

Thiele HU (1977) Carabid beetles in their environments: a study on habitat selection by adaptations in physiology and behaviour. Zoophysiol Ecol 10

Thomas CFG, Cooke H, Bauly J, Marshall EJP (1994) Invertebrate colonization of overwintering sites in different field boundary habitats. Aspects Appl Biol 40:229-232

Thomas CFG, Parkinson L, Marshall EJP (1998) Isolating the components of activity-density for the carabid beetle Pterostichus melanarius in farmland. Oecologia 116:103-112

Thomas CFG, Parkinson L, Griffith GJK, Fernandez Garcia A, Marshall EJP (2001) Aggregation and temporal stability of carabid beetle distributions in field and hedgerow habitats. J Appl Ecol 38:100-116

Tomlin AD (1975) Notes on the biology and rearing of two species of ground beetles, Pterostichus melanarius and Harpalus pennsylvanicus (Coleoptera, Carabidae). Can Ent 107:67-74

Topping CJ, Hansen TS, Gensen TS, Jepsen JU, Nikolajsen F, Odderskaer P (2003) ALMaSS, an agent-based model for animals in temperate European landscapes. Ecol Modell 167(12):65-82

Vickerman GP, Sunderland KD (1977) Some effects of Dimethoate on arthropods in winter wheat. Journal of Applied Ecology, 14: 767777.

Wallin H (1985) Spatial and temporal distribution of some abundant carabid beetles (Coleoptera; Carabidae) in cereal fields and adjacent habitats. Pedobiologia 28:19-34

Wallin H (1988) Effects of spatial distribution on the development and reproduction of Pterostichus cupreus L., P. melanarius Ill., $P$. niger Schall. and Harpalus rufipes Degeer (Col., Carabidae) on arable land. J Appl Entomol 106:483-487

Wallin H, Ekbom B (1988) Movements of carabid beetles (Coleoptera: Carabidae) inhabiting cereal fields: a field tracing study. Oecologia 77:19-43

Wallin H, Ekbom B (1994) Influence of hunger level and prey densities on movement pattern in three species of Pterostichus beetles. Environ Entomol 23:1171-1181

Wratten SD, Van Emden HR (1995) Habitat management for enhanced activity of natural ennemies of insect pests. In: Glen DM, Greaves MP, Anderson HM (eds) Ecology and integrated farming systems. Wiley, Hoboken, pp 117-145 